\title{
A dipeptide transporter from the arbuscular mycorrhizal fungus Rhizophagus irregularis is upregulated in the intraradical phase
}

\section{Simone Belmondo ${ }^{1+}$, Valentina Fiorilli ${ }^{2+}$, Jacob Pérez-Tienda ${ }^{3}$, Nuria Ferrol $^{3}$, Roland Marmeisse ${ }^{1,4}$ and Luisa Lanfranco ${ }^{1 *}$}

${ }^{1}$ Department of Life Sciences and Systems Biology, University of Torino, Torino, Italy

${ }^{2}$ Istituto per la Protezione Sostenibile delle Piante, Consiglio Nazionale delle Ricerche, Torino, Italy

${ }^{3}$ Departamento de Microbiología del Suelo y Sistemas Simbióticos, Consejo Superior de Investigaciones Cientificas, Granada, Spain

${ }^{4}$ Ecologie Microbienne, UMR CNRS 5557 - USC INRA 1364, Université Lyon 1, Université de Lyon, Villeurbanne, France

Edited by:

Pierre-Emmanuel Courty, University

of Basel - Botanical Institute,

Switzerland

Reviewed by:

Soazig Guyomarc'H, Université

Montpellier 2, France

Kevin Garcia, University of

Wisconsin-Madison, USA

*Correspondence:

Luisa Lanfranco, Department of Life Sciences and Systems Biology,

University of Torino, Via Accademia

Albertina 13, 10123 Torino, Italy

e-mail: luisa.lanfranco@unito.it

these authors have contributed equally to this work.
Arbuscular mycorrhizal fungi (AMF), which form an ancient and widespread mutualistic symbiosis with plants, are a crucial but still enigmatic component of the plant micro biome. Nutrient exchange has probably been at the heart of the success of this plant-fungus interaction since the earliest days of plants on land. To characterize genes from the fungal partner involved in nutrient exchange, and presumably important for the functioning of the AM symbiosis, genome-wide transcriptomic data obtained from the AMF Rhizophagus irregularis were exploited. A gene sequence, showing amino acid sequence and transmembrane domains profile similar to members of the PTR2 family of fungal oligopeptide transporters, was identified and called RiPTR2. The functional properties of RiPTR2 were investigated by means of heterologous expression in Saccharomyces cerevisiae mutants defective in either one or both of its di/tripeptide transporter genes PTR2 and DAL5. These assays showed that RiPTR2 can transport dipeptides such as Ala-Leu, Ala-Tyr or Tyr-Ala. From the gene expression analyses it seems that RiPTR2 responds to different environmental clues when the fungus grows inside the root and in the extraradical phase.

Keywords: arbuscular mycorrhizal fungi, organic nitrogen, dipeptide transporter, Rhizophagus irregularis, symbiosis

\section{INTRODUCTION}

Nitrogen $(\mathrm{N})$ is quantitatively the most important soil nutrient for plant growth and productivity. Plants acquire $\mathrm{N}$ not only as nitrate and ammonium that are converted to amino acids in the root or shoot tissues, but also as organic $\mathrm{N}$ forms (i.e., amino acids, peptides, and proteins) from the soil (Näsholm et al., 2009). Free amino acids generally only account for a small fraction of organic $\mathrm{N}$ pool of soil solution whereas peptide- and proteinbound amino acids may contribute to most of the soil organic N pool (Farrell et al., 2011; Hill et al., 2012; Warren, 2014).

Although the ecological significance of organic $\mathrm{N}$ uptake for plant $\mathrm{N}$ nutrition is still a matter of discussion, several lines of evidence suggest that plants inhabiting ecosystems characterized by slow $\mathrm{N}$ mineralization rates may, to a significant degree, rely on organic $\mathrm{N}$ forms for growth (Lipson and Näsholm, 2001).

To make the picture more complex, many plant species form intimate symbioses with mycorrhizal fungi, which constitute a large proportion of the microbial biomass in many soils and may play a crucial role in the N nutrition of their host plants (Girlanda et al., 2007; Fitter et al., 2011).

Mycorrhizal fungi are also known to use different $\mathrm{N}$ sources, depending on specific biochemical, physiological, and ecological features of the fungus involved (Girlanda et al., 2007).
Acquisition of organic $\mathrm{N}$ has traditionally been associated with ectomycorrhizal fungi, which are localized in the upper, organic matter-enriched soil horizons. And, indeed, some ectomycorrhizal fungi have been shown to possess proteolytic capabilities and organic N uptake systems (Wipf et al., 2002; Guidot et al., 2005; Benjdia et al., 2006; Shah et al., 2013).

Arbuscular mycorrhizal (AM) fungi, which form relationships with the majority of plant families in most ecosystems, improve the mineral nutrition of their hosts via an efficient uptake of mineral nutrients from the soil. AM fungi could also be involved in the acquisition of organic and inorganic N (Cappellazzo et al., 2008; Lanfranco et al., 2011; Pérez-Tienda et al., 2012). Arbusculecontaining cells are thought to be the main site for such a nutrient exchange (Bonfante and Genre, 2010). Arbuscules are highly branched fungal structures that develop inside a living cortex cell: each fungal branch is surrounded by a proliferating plant plasma membrane called the periarbuscular membrane.

It has been shown that organic $\mathrm{N}$ uptake is greatly enhanced by AM colonization (Cliquet et al., 1997; Hawkins et al., 2000) and that AM symbiosis could both enhance the decomposition of $\mathrm{N}$ and increase $\mathrm{N}$ capture from organic patches (Hodge et al., 2001). The uptake of exogenously supplied Arg has also been observed in the extraradical mycelium (ERM) grown in in vitro 
cultures (Govindarajulu et al., 2005; Fellbaum et al., 2012). Apart from the capability of taking up amino acids, there is increasing evidence that AM fungi could increase $\mathrm{N}$ capture from more complex organic material (Hodge et al., 2001; Leigh et al., 2009; Whiteside et al., 2013).

$\mathrm{N}$ uptake requires the activity of transporters that transfer the $\mathrm{N}$ compounds across cellular membranes. Regarding organic N, the only transporter so far described in AM fungi is GmosAAP1, an amino acid permease from Funneliformis mosseae (Cappellazzo et al., 2008) which may play a role in the first steps of amino acid uptake from the soil. No data are so far available for peptide transporters.

At least four distinct plasma membrane, proton-coupled peptide transport systems have been described in fungi, and in other eukaryotic organisms. Transporters belonging to PTR, DAL5 and FOT families transport di- and tripeptides, while those belonging to OPT family transport longer tetra- and pentapeptides (Hauser et al., 2001; Homann et al., 2005; Reuß and Morschhäuser, 2006; Damon et al., 2011; Hartmann et al., 2011; Dunkel et al., 2013). In Saccharomyces cerevisiae, PTR2 is the only member of the PTR family. Mutants lacking PTR2 were found to have lost the ability to utilize numerous, but not all, di- and tripeptides as a source of required amino acids (Perry et al., 1994). More recent studies showed that the allantoate/ureidosuccinate permease DAL5, contributes to the uptake of the di- and tripeptides that a ptr $2 \Delta$ mutant continued to assimilate (Homann et al., 2005; Cai et al., 2007).

Several PTR members have also been identified in plants and exhibit various functions (Dietrich et al., 2004; Karim et al., 2005; Komarova et al., 2008). For example, in Arabidospis thaliana AtPTR5 facilitates peptide transport into germinating and possibly maturing pollen, ovules, and seeds while AtPTR1 has a role in uptake of peptides by roots (Komarova et al., 2008).

In this study we performed the first functional characterization of a putative dipeptide transporter RiPTR2 from the AM fungus $R$. irregularis which was previously shown to be differentially expressed between mycorrhizal roots and ERM (Tisserant et al., 2012). We further addressed its regulation pattern in intra- and extraradical fungal structures challenged with different $\mathrm{N}$ sources in order to understand its potential role in the fungal nutrition and symbiotic interaction.

\section{MATERIALS AND METHODS}

\section{BIOLOGICAL MATERIALS, GROWTH CONDITIONS, AND TREATMENTS}

Rhizophagus irregularis (Syn. Glomus intraradices, DAOM 197198; Krüger et al., 2012) inoculum for seedlings and root organ cultures (ROCs) mycorrhization, was produced through in vitro monoxenic cultures. These were established in bi-compartmental Petri dishes with a watertight plastic wall separating the root compartment (RC) from the hyphal compartment (HC) (Fortin et al., 2002). The RC was filled with $25 \mathrm{ml}$ of solid $\mathrm{M}$ minimal medium and the HC with $25 \mathrm{ml}$ of solid M medium lacking sugar (M-C). Cultures were started by placing an explant of Agrobacterium rhizogenes transformed-chicory (Cichorium intybus) roots colonized with the AM fungus in the RC. Once the mycelium of $R$. irregularis had grown over the plastic wall and completely filled the $\mathrm{HC}$ compartment, the medium was dissolved with sterile $10 \mathrm{mM}$ citrate buffer, $\mathrm{pH}$ 6.0. Spores were then collected and used for plant inoculation.

To obtain the ERM, when the fungus profusely colonized the $\mathrm{HC}$, its content was removed, and the $\mathrm{HC}$ was filled with $15 \mathrm{ml}$ liquid M-C medium containing either $3.2 \mathrm{mM}(100 \% \mathrm{~N})$ or $0.8 \mathrm{mM}(25 \% \mathrm{~N}) \mathrm{KNO}_{3}^{-}$. The mycelium was allowed to colonize this medium over the subsequent 2 weeks. Petri dishes were examined regularly and roots were trimmed as required to prevent crossing into the $\mathrm{HC}$.

For the dipeptide treatments, ERM was grown for 2 weeks in liquid $\mathrm{M}$ medium $\left(100 \% \mathrm{~N}\right.$ as $\left.\mathrm{KNO}_{3}^{-}\right)$. At this point, the medium of the $\mathrm{HC}$ was removed and replaced by fresh liquid $\mathrm{M}-\mathrm{C}$ medium containing as nitrogen sources $3.2 \mathrm{mM}$ nitrate, $3.2 \mathrm{mM}$ nitrate and $10 \mathrm{mM}$ Ala-Leu, $10 \mathrm{mM}$ Ala-Leu or no N. ERM was harvested after $24 \mathrm{~h}$.

In both experiments, ERM was collected with tweezers, rinsed with sterilized water, dried with sterilized filter paper, immediately frozen in liquid $\mathrm{N}$ and stored at $-80^{\circ} \mathrm{C}$ until used.

To obtain seedlings colonized by $R$. irregularis, the Millipore sandwich method (Giovannetti et al., 1993) was used. Seeds of Medicago truncatula Gaertn cv Jemalong were first scarified using sandpaper P180-200, sterilized with 5\% commercial bleach for $3 \mathrm{~min}$ and rinsed three times for $10 \mathrm{~min}$ with sterile distilled water. Germination was induced under sterile conditions in $0.6 \%$ agar/water, incubated for 5 days in the dark $\left(25^{\circ} \mathrm{C}\right)$ and then exposed at the light for 4 days. Plants were watered with a modified Long-Ashton (LA) solution containing $3.2 \mu \mathrm{M}$ $\mathrm{Na}_{2} \mathrm{HPO}_{4} \cdot 12 \mathrm{H}_{2} \mathrm{O}$ and $0.5 \mathrm{mM} \mathrm{NaNO}_{3}$ nitrate as $\mathrm{P}$ and $\mathrm{N}$ sources, respectively (Hewitt, 1966) and were grown in a growth chamber under $14 \mathrm{~h}$ light $\left(24^{\circ} \mathrm{C}\right) / 10 \mathrm{~h}$ dark $\left(20^{\circ} \mathrm{C}\right)$ regime. Plants were harvested 60 days post-inoculation (dpi).

For the dipeptide treatment, in a first experiment, $M$. truncatula mycorrhizal roots were obtained in pot cultures watered with a LA solution containing $1 \mathrm{mM}$ nitrate. Two months after inoculation, mycorrhizal roots were treated for $24 \mathrm{~h}$ in hydroponic conditions with a LA solution containing $10 \mathrm{mM}$ Ala-Leu or $1 \mathrm{mM}$ nitrate or no N. In a second experiment $M$. truncatula mycorrhizal roots were grown in the sandwich system as described above for 60 days with a modified LA solution containing $2.5 \mathrm{mM}$ Ala-Leu and $0.25 \mathrm{mM}$ nitrate as $\mathrm{N}$ sources.

For mycorrhizal plants, only portions of the root system showing extraradical fungal structures were collected under a stereomicroscope. The colonization level was assessed according to Trouvelot et al. (1986). For the molecular analyses, roots were immediately frozen in liquid nitrogen and stored at $-80^{\circ} \mathrm{C}$.

\section{SEQUENCE ANALYSES}

Fungal protein sequences homologous to PTR2 transporters were identified by BLASTp searches within the Mycocosm database (Grigoriev et al., 2014). Prediction of trans-membrane domains was performed using TMHMM (http://www.cbs.dtu.dk/services/TMHMM-2.0/), SOSUI (http://harrier.nagahama-i-bio.ac.jp/sosui/), HMMTOP (http://www.enzim.hu/hmmtop/) and TMpred (http://www.ch. embnet.org/software/TMPRED_form.html) programs.

Amino acid sequences were aligned using MUSCLE (Edgar, 2004) and their phylogenetic links inferred by using the 
Maximum Likelihood method based on the JTT matrix-based model (Jones et al., 1992) as implemented in MEGA5 (Tamura et al., 2011).

\section{YEAST COMPLEMENTATION ASSAYS}

The coding region of RiPTR2 was amplified from $R$. irregularis cDNAs by PCR using Phusion DNA-Polymerase (Finnzymes, Espoo, Finland) and the two following oligonucleotides containing a NotI restriction site: forward primer, 5' -TGACATTGCGGCCGCATAATGGAAGGACACATTCAA-3'; reverse primer, 5'-ACTTCGAGCGGCCGCTGTGACTATTC TTCGGATTTA-3'. The PCR product was cloned into NotI sites downstream of the $S$. cerevisiae constitutive PGK1 promoter in the pFL61 E. coli-yeast shuttle vector (Minet et al., 1992). Recombinant (pRiPTR2) and empty vector (EV) were used to transform W303 (MATa ura3 can1-100) yeast mutants deleted of only one or of its two known dipeptide transporter genes, PTR2 and DAL5 (Homann et al., 2005).

Yeast transformation was performed using standard protocols (Rose et al., 1990) and yeast transformants propagating either the EV or the pRiPTR2 recombinant vector were initially selected on a yeast nitrogen base minimal medium lacking uracil. Single colonies of transformants were grown over night in $5 \mathrm{ml}$ of $\mathrm{NH}_{4}^{+}$-containing yeast carbon base (YCB) liquid medium. Once the $\mathrm{OD}_{600 \mathrm{~nm}}$ reached 0.9 , serial dilutions (1:10-1:100-1:1000$1: 10,000)$ in sterile water were prepared and $5 \mathrm{ml}$ plated on YCB solid medium containing $\mathrm{H}_{2} \mathrm{O}$ (negative control), $\mathrm{NH}_{4}^{+}$(positive control), Ala-Tyr, Tyr-Ala or Ala-Leu ( $0.25 \mathrm{mM}$ each). Plates were incubated at $30^{\circ} \mathrm{C}$ for 4 days and photographed.

\section{NUCLEIC ACID EXTRACTION AND RT-qPCR ASSAYS}

Total genomic DNA was extracted from $R$. irregularis extraradical structures and M. truncatula and C. intybus roots using the DNeasy Plant Mini Kit (Qiagen), according to the manufacturer's instructions.

Total RNA was isolated from about $100 \mathrm{mg}$ of seedling roots and $20 \mathrm{mg}$ ERM using the RNeasy Plant Mini Kit (Qiagen). Samples were treated with TURBO ${ }^{\mathrm{TM}}$ DNase (Ambion) according to the manufacturer's instructions. The RNA samples were routinely checked for DNA contamination by RT-PCR analysis, using primers MtTefF 5'-AAGCTAGGAGGTATTGACAAG-3' and MtTefR $5^{\prime}$-ACTGTGCAGTAGTACTTGGTG-3' for $\mathrm{MtTEF}$ or RiTef-f $5^{\prime}$-GCTATTTTGATCATTGCCGCC-3' and RiTef-r 5'-TCATTAAAACGTTCTTCCGACC-3' for RiTEF (GonzàlezGuerrero et al., 2010) and the One-Step RT-PCR kit (Qiagen). The MtPT4 phosphate transporter gene was amplified with MtPT4F (5'-TCGCGCGCCATGTTTGTTGT-3') and MtPT4R (5'-CGCAAGAAGAATGTTAGCCC-3') primers (Zocco et al., 2011) and the RiPTR2 peptide transporter with RiPTR2F (5'-GGCTATATTCTTAACGATGTCG- $\left.3^{\prime}\right)$ and RiPTR2R (5'CGACCTGTTCTTCTTCCTCTT- $3^{\prime}$ ) primers. Conventional PCR assays on plant genomic DNA excluded any cross-hybridization of RiPTR2 specific primers.

For single-strand cDNA synthesis about $500 \mathrm{ng}$ of total RNA were denatured at $65^{\circ} \mathrm{C}$ for $5 \mathrm{~min}$ and then reverse-transcribed at $25^{\circ} \mathrm{C}$ for $10 \mathrm{~min}, 42^{\circ} \mathrm{C}$ for $50 \mathrm{~min}$ and $70^{\circ}$ for $15 \mathrm{~min}$ in a final volume of $20 \mu \mathrm{l}$ containing $10 \mu \mathrm{M}$ random hexamers, $0.5 \mathrm{mM}$
dNTPs, $4 \mu \mathrm{l} 5 \times$ buffer, $2 \mu l 0.1$ M DTT, and $1 \mu$ l Super-ScriptII (Invitrogen).

qRT-PCR experiments were carried out in a final volume of $20 \mu \mathrm{l}$ containing $10 \mu \mathrm{l}$ of $\mathrm{iTaq}^{\mathrm{TM}}$ Universal SYBR ${ }^{\circledR}$ Green Supermix (Bio-Rad), $1 \mu \mathrm{l}$ of $3 \mu \mathrm{M}$ specific primers, and about $20 \mathrm{ng}$ of cDNA. Samples were run in the iCycler iQ apparatus (Bio-Rad) using the following program: $10 \mathrm{~min}$ pre-incubation at $95^{\circ} \mathrm{C}$, followed by 40 cycles of $15 \mathrm{~s}$ at $95^{\circ} \mathrm{C}$, and $1 \mathrm{~min}$ at $60^{\circ} \mathrm{C}$. Each amplification was followed by melting curve analysis $\left(60-94^{\circ} \mathrm{C}\right)$ with a heating rate of $0.5^{\circ} \mathrm{C}$ every $15 \mathrm{~s}$. All reactions were performed with three technical replicates and only $\mathrm{Ct}$ values with a standard deviation that did not exceed 0.3 were considered. The comparative threshold cycle method (Rasmussen, 2001) was used to calculate relative expression levels using the plant $M t T E F$ or the fungal RiTEF as reference genes for plant and fungal genes, respectively. The analyses were performed on three independent biological replicates. Statistical tests were carried out through one-way analysis of variance (One-Way ANOVA) and Tukey's post-hoc test, using a probability level of $p<0.05$. All statistical analyses were performed using the PAST statistical package (version 2.16; Hammer et al., 2001).

\section{SEMI-QUANTITATIVE RT-PCR ON LASER MICRODISSECTED CELLS}

$M$. truncatula roots colonized by $R$. irregularis obtained with the millipore sandwich system, as described above, were cut into 5-10 mm-long pieces, treated with ethanol and glacial acetic acid (3:1) under vacuum for $30 \mathrm{~min}$ and then placed at $4^{\circ} \mathrm{C}$ overnight. Roots were subsequently dehydrated in a graded series of ethanol (50\%-70\%-90\% in sterilized water and 100\% twice) followed by Neoclear (twice) with each step on ice for $30 \mathrm{~min}$. Neoclear was gradually replaced with paraffin (Paraplast Plus; Sigma-Aldrich, St. Louis) according to Pérez-Tienda et al. (2011). A Leica AS LMD system (Leica Microsystem, Inc.) was used to collect colonized cortical cells from paraffin root sections as described by Balestrini et al. (2007).

RNA was extracted from dissected cells using the PicoPure kit protocol (Arcturus Engineering). A DNAse treatment was performed using an RNA-free DNase Set (Qiagen) in a Pico Pure column, according to the manufacturer's instructions and RNAs were eluted in $21 \mu \mathrm{l}$ of sterile water.

All RT-PCR assays were carried out using the One Step RTPCR kit (Qiagen). DNA contaminations were assessed using the MtTEF primers described above. Reactions with RiPTR2 or $M t P T 4$ specific primers were carried out in a final volume of $10 \mu \mathrm{l}$ containing $2 \mu \mathrm{l}$ of $5 \times$ buffer, $0.4 \mu \mathrm{l}$ of $10 \mathrm{mM}$ dNTPs, $1 \mu \mathrm{l}$ of each primer $10 \mathrm{mM}, 0.2 \mu \mathrm{l}$ of One Step RT-PCR enzyme mix, and $1 \mu \mathrm{l}$ of a total RNA diluted $1: 1$. The samples were incubated for $30 \mathrm{~min}$ at $50^{\circ} \mathrm{C}$, followed by $15 \mathrm{~min}$ incubation at $95^{\circ} \mathrm{C}$. Amplification reactions were run for 40 cycles of $94^{\circ} \mathrm{C}$ for $30 \mathrm{~s}, 60^{\circ} \mathrm{C}$ for $30 \mathrm{~s}$, and $72^{\circ} \mathrm{C}$ for $40 \mathrm{~s}$. RT-PCR experiments were conducted on two different biological replicates of 1500-2000 microdissected cells each.

\section{RESULTS}

With the aim to characterize fungal genes involved in fungal/plant nutrient exchange and, possibly, in the functioning of arbuscules, the key structures of the AM symbiosis, we 
exploited transcriptomics data (Tisserant et al., 2012) generated for the AM fungus $R$. irregularis (Syn. G. intraradices; Krüger et al., 2012). We focused our attention on an EST (contig step3_c3279 of MIRA v2 assembly) that, from the microarray data, showed a 33 fold up-regulation in the intraradical mycelium (IRM) compared to the ERM (Tisserant et al., 2012). The sequence, containing a full length ORF of 547 amino acids, had been annotated as an oligopeptide transporter. BLAST searches indicated a similarity to fungal Major Facilitator Superfamily (MFS) di/tripeptide transporters. In particular, the sequence possesses the PTR2[pfam00854] conserved domain that characterizes the proton-dependent oligopeptide transporters (PTR, T.C.2.A.17) family. For this reason, it was called RiPTR2.

Recent releases of the complete genome sequence of $R$. irregularis (Tisserant et al., 2013; Lin et al., 2014) allowed us to assess that RiPTR2 is a single copy gene containing four introns (Figure $\mathrm{S} 1$ ). Twelve transmembrane domains were predicted for RiPTR2 amino acid sequence (Figures S1,S2) using HMMTOP, TMHMM, SOSUI, and TMPRED programs. This structure is similar to that of the well characterized PTR2 sequence from S. cerevisiae which shows $40.8 \%$ identity at the amino acid level to RiPTR2.

Two putative homologs were found within an extensive transcripts dataset of another AM fungus, Gigaspora margarita (Salvioli et al., in preparation), which is phylogenetically distant from $R$. irregularis. The two deduced amino acid sequences, named GmarPTR2A and GmarPTR2B show 56.2 and $51.7 \%$ identity to RiPTR2, respectively.

A phylogenetic analysis was carried out by Maximum Likelihood method using PTR2 sequences from a number of fungi representative of distinct taxonomic groups retrieved from the MycoCosm (Grigoriev et al., 2014) genomic database (Figure 1; Table S1). RiPTR2 grouped with the two G. margarita sequences to form a well-supported sequence cluster clearly separated from sequences from Ascomycota, Basidiomycota and Zygomycota species.

\section{RiPTR2 ENCODES A FUNCTIONAL DIPEPTIDE TRANSPORTER}

To verify whether RiPTR2 encodes a functional peptide transporter, it was expressed in S. cerevisiae W303 mutant strains

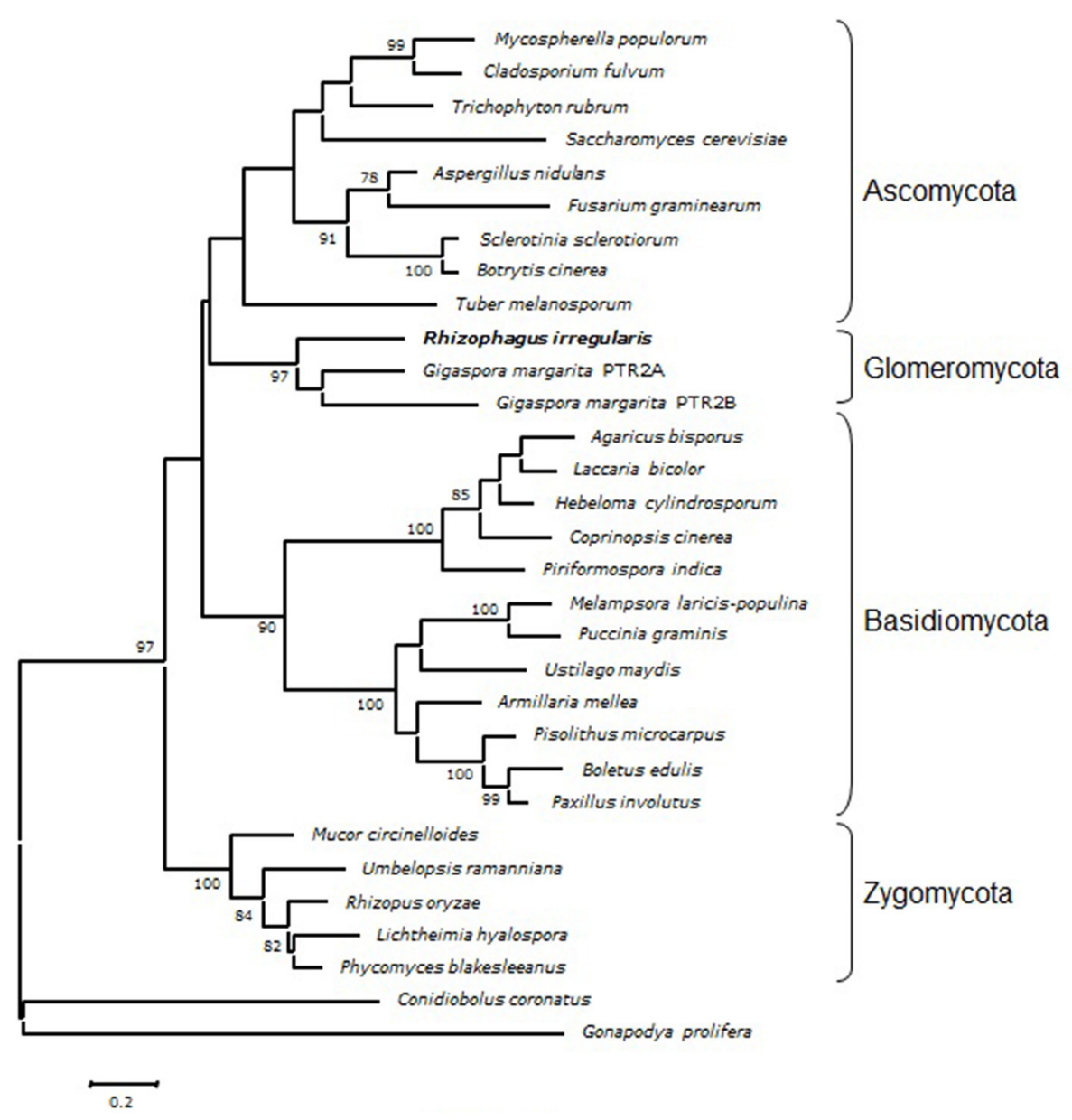

FIGURE 1 | Phylogenetic position of RiPTR2 protein sequence in comparison with homologous sequences from selected species representative of the major fungal phyla (Table S1). The evolutionary history was inferred by using the Maximum Likelihood method based on the
JTT matrix-based model as implemented in MEGA5. The percentage of trees higher than $75 \%$ in which the associated taxa clustered together is shown next to the branches. The tree is drawn to scale, with branch lengths measured in the number of substitutions per site. 
deleted of either one or both of its two endogenous di/tripeptide transporter genes, PTR2 and DAL5. Both single (ptr2 $\Delta$ or dal5 $\Delta$ or double (ptr $2 \Delta$ dal5 $\Delta$ ) mutant strains are unable to use many dipeptides as $\mathrm{N}$ sources (Homann et al., 2005).

RiPTR2-expressing yeast transformants were plated onto selective media, containing one of three different dipeptides as $\mathrm{N}$ sources; Ala-Tyr, Tyr-Ala or Ala-Leu. Tyr-Ala is known to be a substrate for the yeast Ptr2p but not for Dal5p, while Ala-Leu is used by Dal5p but not by Ptr2p, and Ala-Tyr is neither used by Ptr2p nor by Dal5p in the W303 background (Homann et al., 2005). In addition, $\mathrm{H}_{2} \mathrm{O}$ and $\mathrm{NH}_{4}^{+}$were used as negative and positive control, respectively.

All transformants (empty or recombinant vector) were unable to grow in $\mathrm{N}$-free medium $\left(\mathrm{H}_{2} \mathrm{O}\right)$ although a background growth could be observed probably due to residual traces of $\mathrm{N}$ compounds present in the agar. As expected, all transformants were able to grow in the $\mathrm{NH}_{4}^{+}$-containing medium, Interestingly, ptr $2 \Delta$ dal5 $\Delta$ cells expressing RiPTR2 grew on Ala-Leu, Ala-Tyr and also Tyr-Ala, whereas no growth was observed for ptr $2 \Delta$ dal5 $\Delta$ cells transformed with the EV, indicating that RiPTR2 is able to transport these three dipeptides (Figure 2).

Ala-Leu and Ala-Tyr transport in the dal5 $\Delta$ single mutant expressing RiPTR2 was also evident (Figure 2). Results obtained with ptr $2 \Delta$ single mutant were difficult to interpret since this mutant, transformed with the EV, showed a high background growth on all three dipeptides. However, RiPTR2 transformants clearly diplayed an increased growth on all three dipeptides.

Taken as a whole these results demonstrated that RiPTR2 codes for a functional dipeptide transporter.

\section{RiPTR2 EXPRESSION PROFILES}

We first compared the expression profile of RiPTR2 in intraradical (IRM) and extraradical (ERM) mycelia by quantitative RT-PCR from $M$. truncatula plants colonized by $R$. irregularis grown in $0.5 \mathrm{mM}$ nitrate in the sandwich system. RNA extractions were performed on ERM and on roots fragments from which the ERM was carefully removed to produce the IRM sample. Samples were normalized with the RiTEF housekeeping gene. A strong RiPTR2 expression was observed in the IRM while RiPTR2 transcripts were less abundant, and almost barely detected, in the ERM (Figure 3A). A similar result was obtained considering mycorrhizal roots of $C$. intybus devoided of ERM, grown in the root compartment and ERM developed in the hyphal compartment of the same ROC (Figure 3B). These results thus confirmed the strong expression in the IRM as observed in the microarray data (Tisserant et al., 2012).

We also performed a time course experiment in the sandwich system to determine RiPTR2 transcript abundance at different times $(7,14,28$, and 60 days) post-inoculation (dpi) of

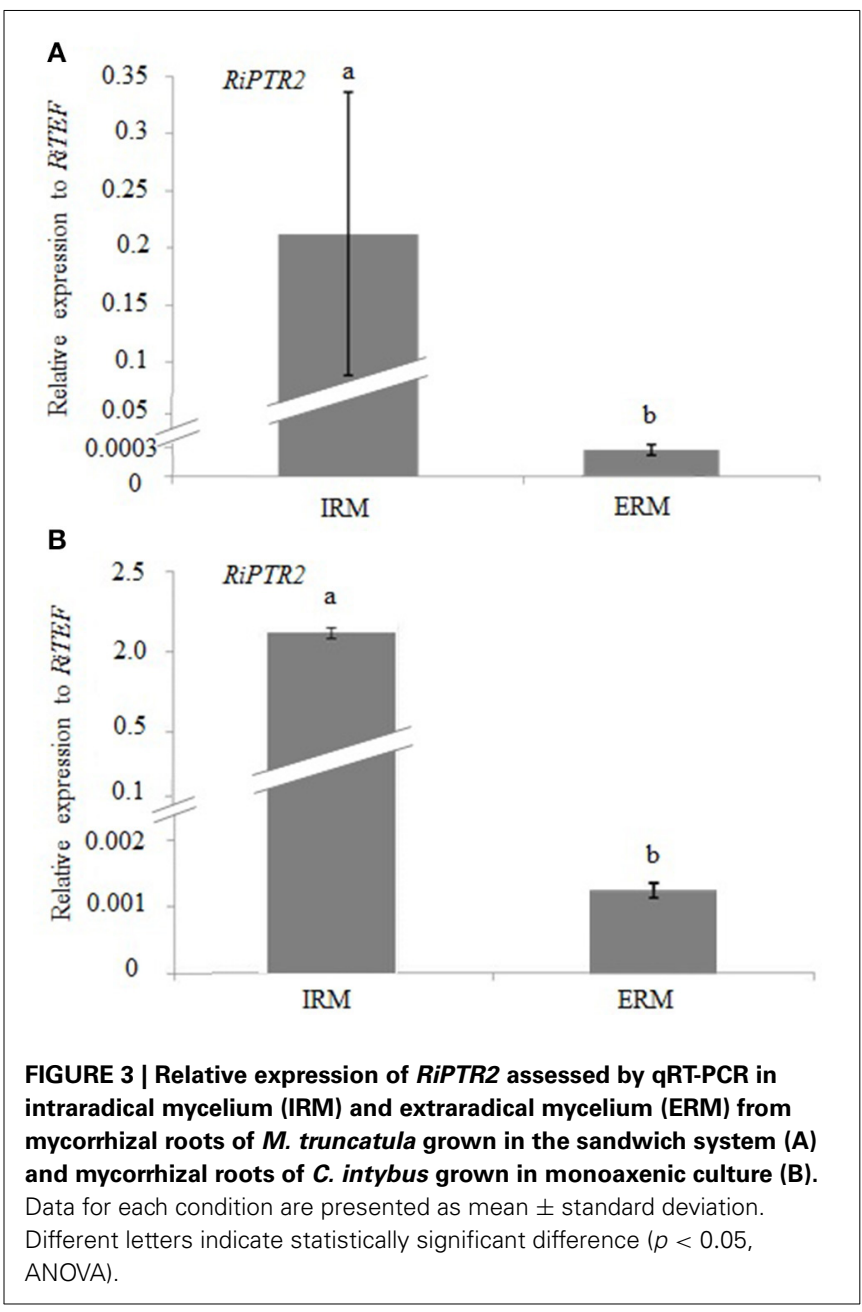

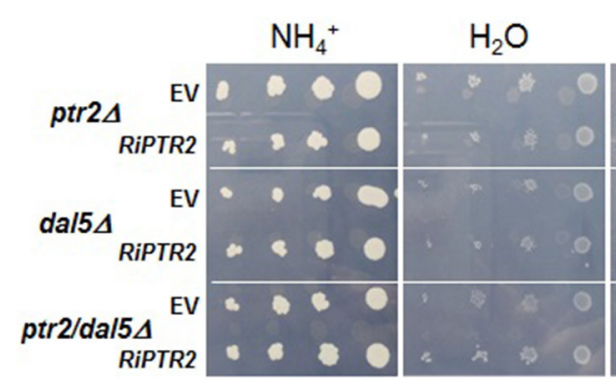

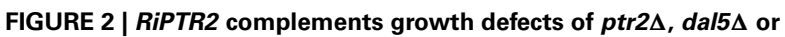
ptr2 $\Delta$ dal5 $\Delta$ yeast transporter mutants on dipeptides. Serial dilutions (1:10-1:100-1:1,000-1:10,000 from left to right) of cultured strains

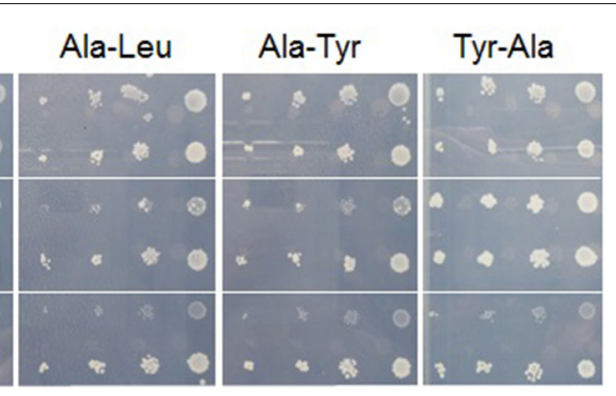

transformed with RiPTR2 or the empty vector (EV) were plated on YCB solid medium containing $\mathrm{H}_{2} \mathrm{O}$ (negative control), $\mathrm{NH}_{4}^{+}$(positive control), $0.25 \mathrm{mM}$ Ala-Tyr, Tyr-Ala or Ala-Leu. Plates were incubated at $30^{\circ} \mathrm{C}$ for 4 days. 
M. truncatula plants. Morphological analyses of roots showed almost no fungal structures at 7 or $14 \mathrm{dpi}$, while mycorrhization frequency increased from 28 to $60 \mathrm{dpi}$. Arbuscules were visible starting from $28 \mathrm{dpi}$ and were slightly less abundant at $60 \mathrm{dpi}$ than at $28 \mathrm{dpi}$ (Figure S3). Since in the ERM RiPTR2 is expressed at negligible levels, gene expression was evaluated in whole mycorrhizal roots, without making a distinction between IRM and ERM. RiPTR2 mRNA abundance increased in parallel to the development of the intraradical phase as demonstrated by morphological data and the parallel mRNA accumulation of MtPT4, the $M$. truncatula phosphate transporter-encoding gene which is considered a molecular marker of arbuscule-containing cells (Harrison et al., 2002; Figures 4A,B).

The laser microdissection technique was used to specifically obtain RNA from M. truncatula arbusculated cells. The

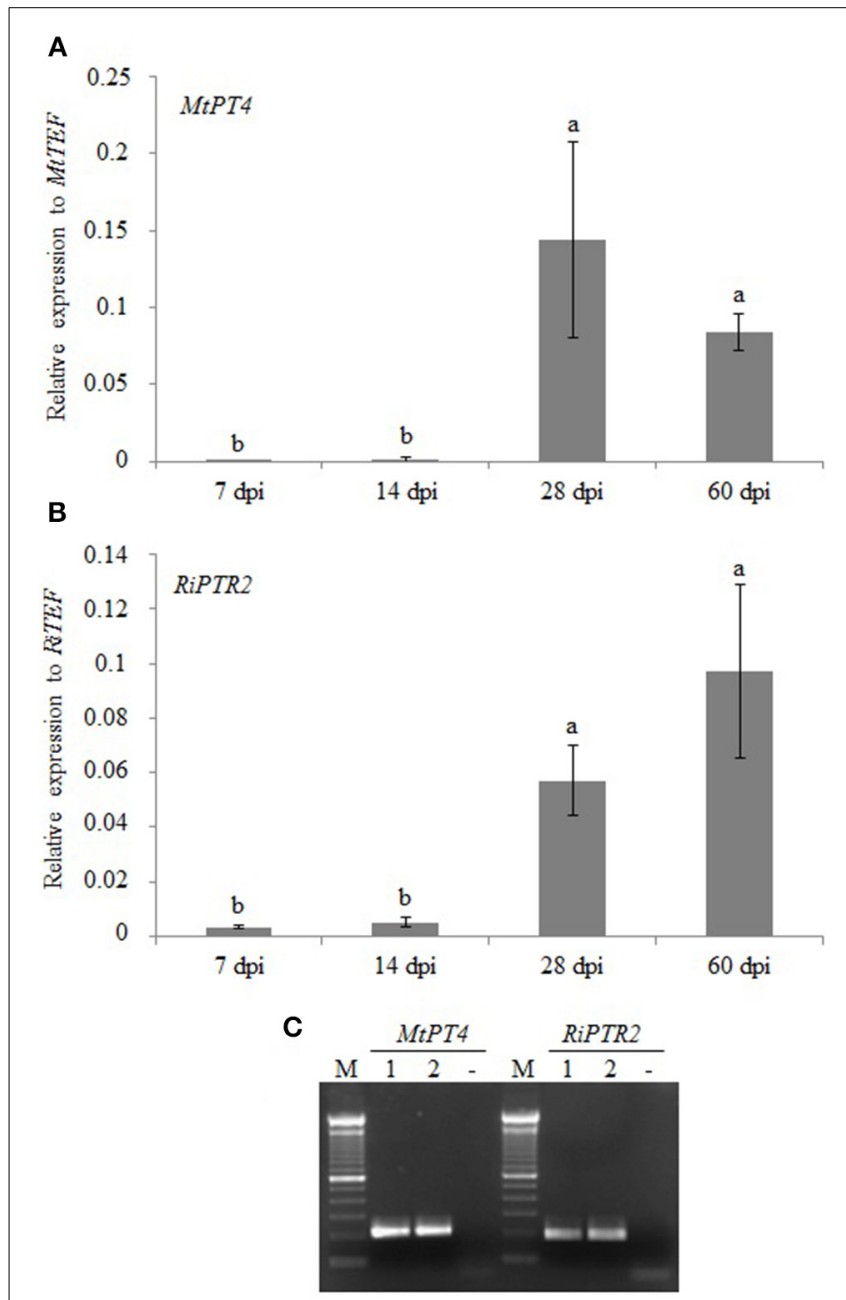

FIGURE 4 | Relative expression of MtPT4 (A) and RiPTR2 (B) assessed by qRT-PCR in a time course experiment of root colonization at 7, 14, 28 and 60 days post-inoculation (dpi). Data for each condition are presented as mean \pm standard deviation. Different letters indicate statistically significant difference ( $p<0.05$, ANOVA). (C) Gel electrophoresis of RT-PCR products obtained from two independent samples $(1,2)$ of RNA from

laser-microdissected arbuscule-containing cells using primers specific for MtPT4 or RiPTR2. No RNA sample (-); M: 100 bp (Invitrogen). authenticity of the samples was verified using MtPT4 specific primers. RiPTR2 mRNA was detected in the two independent samples analyzed, indicating that, under these conditions, in planta RiPTR2 expression occurred in arbuscules (Figure 4C).

We then investigated whether the presence of a dipeptide (AlaLeu), a candidate substrate of RiPTR2 as indicated by the yeast heterologous expression, could modulate RiPTR2 expression levels. This was tested in both a short- and in a long-term exposure experiments where we evaluated the RiPTR2 expression in whole mycorrhizal roots, without making a distinction between IRM and ERM.

In the first experiment (short term exposure), M. truncatula mycorrhizal plants were obtained in pot cultures watered with a Long Ashton (LA) nutrient solution containing $1 \mathrm{mM}$ nitrate. After 2 months mycorrhizal roots were treated for $24 \mathrm{~h}$ in hydroponic conditions with a LA solution containing $10 \mathrm{mM}$ Ala-Leu or $1 \mathrm{mM}$ nitrate or no N. No significant difference was observed in RiPTR2 expression levels among the different treatments (Figure 5A). Plants showed rather similar mycorrhization degrees as revealed by the MtPT4 expression levels; although no $\mathrm{N}$ samples had higher values, they were not statistically different from those of the other two treatments (Figure 5B).

We also investigated whether the RiPTR2 expression in the ERM developed in the ROC system was responsive to $24 \mathrm{~h}$ exposure to $10 \mathrm{mM}$ Ala-Leu. As previously observed RiPTR2

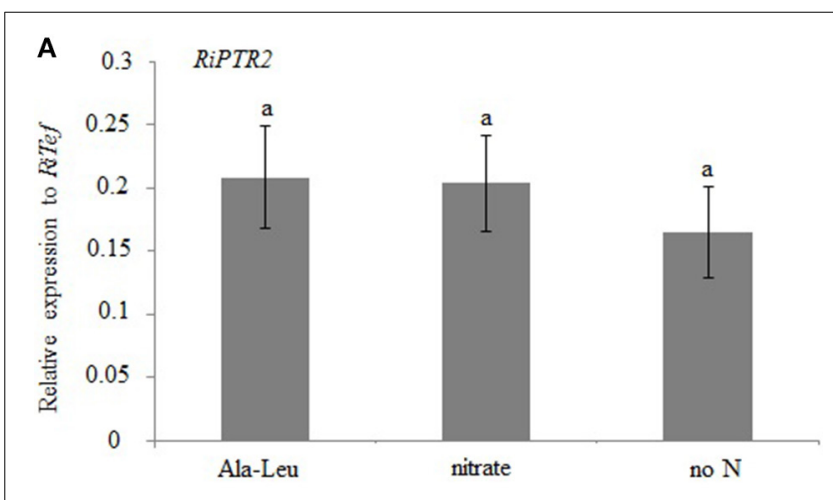

B

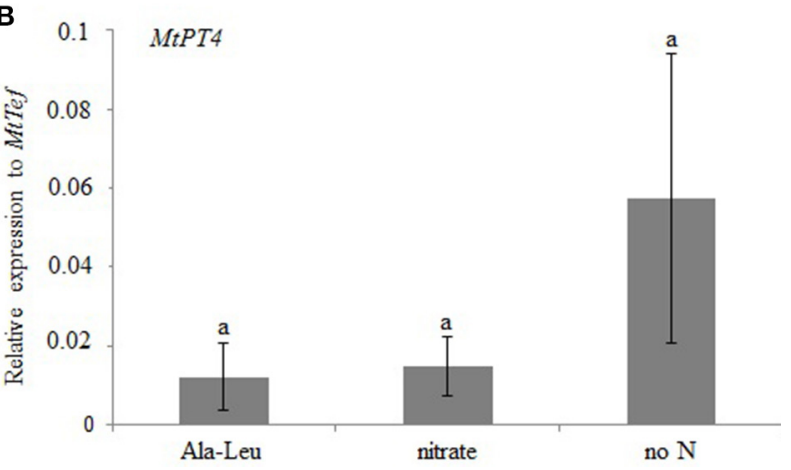

FIGURE 5 | Relative expression of RiPTR2 (A) assessed by qRT-PCR in mycorrhizal roots exposed for $24 \mathrm{~h}$ to $10 \mathrm{mM}$ Ala-Leu, $1 \mathrm{mM}$ nitrate or no N. MtPT4 expression was used as marker of mycorrhization (B). Data for each condition are presented as mean \pm standard deviation. Different letters indicate statistically significant difference ( $p<0.05$, ANOVA). 
expression in the ERM was extremely low (Figure 3) and this treatment led to an apparent decrease of RiPTR2 mRNA abundance compared to the ERM kept for $24 \mathrm{~h}$ in a medium containing $3.2 \mathrm{mM}$ nitrate or no nitrogen (Figure 6).

In the second experiment (long term exposure), M. truncatula mycorrhizal and non-inoculated plants were grown in the sandwich system for 60 days with a nutrient solution containing $2.5 \mathrm{mM}$ Ala-Leu and $0.25 \mathrm{mM}$ nitrate as $\mathrm{N}$ sources. Mycorrhizal plants grown in standard nutrient solution, that is $0.5 \mathrm{mM}$ nitrate, were used as controls. Independently from the AM colonization, plants grown in the presence of Ala-Leu + nitrate have total (shoot + root) biomasses lower than plants grown in only nitrate (Figure 7A). Interestingly, when shoot to root ratio is considered, it appears that the mycorrhization has a positive effect on the plant in the presence of Ala-Leu + nitrate, in particular in resource allocation into shoots (Figure 7B). This result suggests that the AM fungal colonization contributes to the more efficient use of $\mathrm{N}$, including dipeptides. This result may also be due to the higher colonization level as revealed by the MtPT4 expression (Figure 8B). No difference in RiPTR2 transcript abundance was observed in the two conditions (Figure 8A).

\section{DISCUSSION}

Organic $\mathrm{N}$ dominates the $\mathrm{N}$ pool of the majority of soils (Schimel and Bennet, 2004). A key concept under revision is that soil microbes have a greater ability to use organic $\mathrm{N}$ than plants: indeed there is evidence that plants not only take up organic $\mathrm{N}$ (Komarova et al., 2008) but may also compete with microbes for it, although it remains debated how competitive plants are (Kuzyakov and $\mathrm{Xu}, 2013$ ).

Recent works have shown that, in soils, short peptides represent a greater proportion of $\mathrm{N}$ than free amino acids, although there is no detailed information on the availability of individual peptides due to their multiplicity and the lack of a suitable detection system (Hill et al., 2012). Among the peptide uptake systems, the PTR family comprises proton driven symporters which are present in bacteria, fungi, plants and animals. Human PTR transporters have been extensively studied as they are the

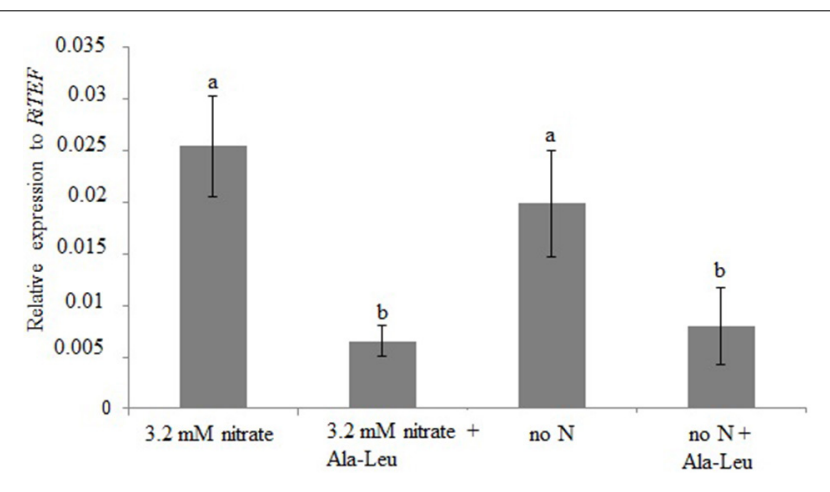

FIGURE 6 | Relative expression of RiPTR2 assessed by qRT-PCR in the extraradical mycelium developed in ROC exposed for $24 \mathrm{~h}$ to $10 \mathrm{mM}$ Ala-Leu or 3.2 mM nitrate or no N. Data for each condition are presented as mean \pm standard deviation. Different letters indicate statistically significant difference ( $p<0.05$, ANOVA). main route through which the body absorbs and retain dietary protein (Newstead, 2014). Despite their potential importance in the $\mathrm{N}$ cycle (Schmidt et al., 2014), still very little is known on PTR from plants or soil fungi.

In this work we have characterized RiPTR2, a PTR transporter from the fungus $R$. irregularis, a model species for the ecologically and agriculturally important group of the Glomeromycota. Searches within the two complete genome sequences of $R$. irregularis so far available (Tisserant et al., 2013; Lin et al., 2014) showed that RiPTR2 is a single copy gene. Interestingly, two putative homologs have been identified within a transcriptome of another AM fungus, G. margarita, which belongs to a distinct family of Glomeromycota. PTR2 gene redundancy has also been found in the genomes of several filamentous fungi (Vizcaíno et al., 2006), including the ectomycorrhizal fungus Hebeloma cylindrosporum which is, to our knowledge, the only mycorrhizal fungus with characterized PTR2 genes (Benjdia et al., 2006).

The RiPTR2 sequence was able to complement the growth defects of yeast mutants defective of the two well studied dipeptide transporters. At least in the heterologous system, RiPTR2 was able to transport Ala-Leu, Ala-Tyr and Tyr-Ala but it is likely that other dipeptides can be transported. Substrate promiscuity is in fact a common feature shared by all peptide uptake systems although the molecular basis of this phenomenon is still an open question (Newstead, 2014). On the other hand, this low substrate specificity has the advantage to avoid restricting uptake to only a subset of the available peptides.

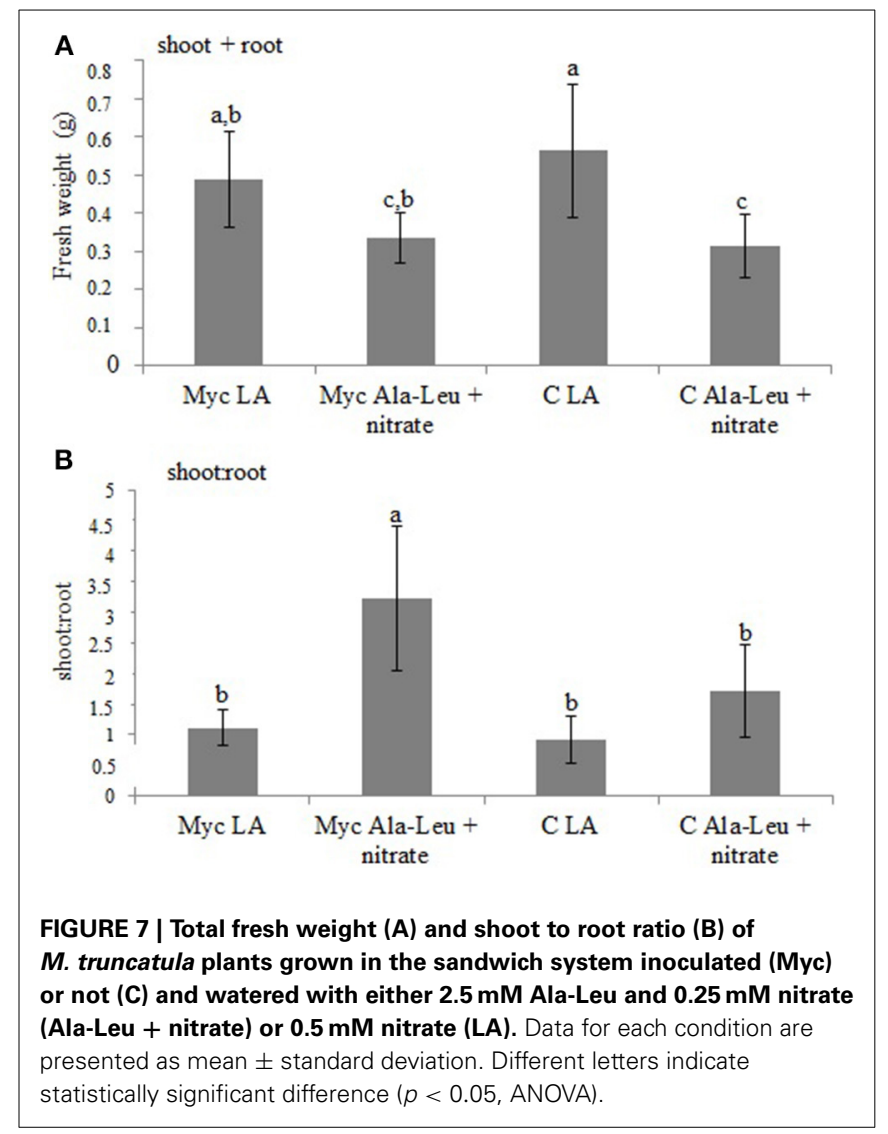




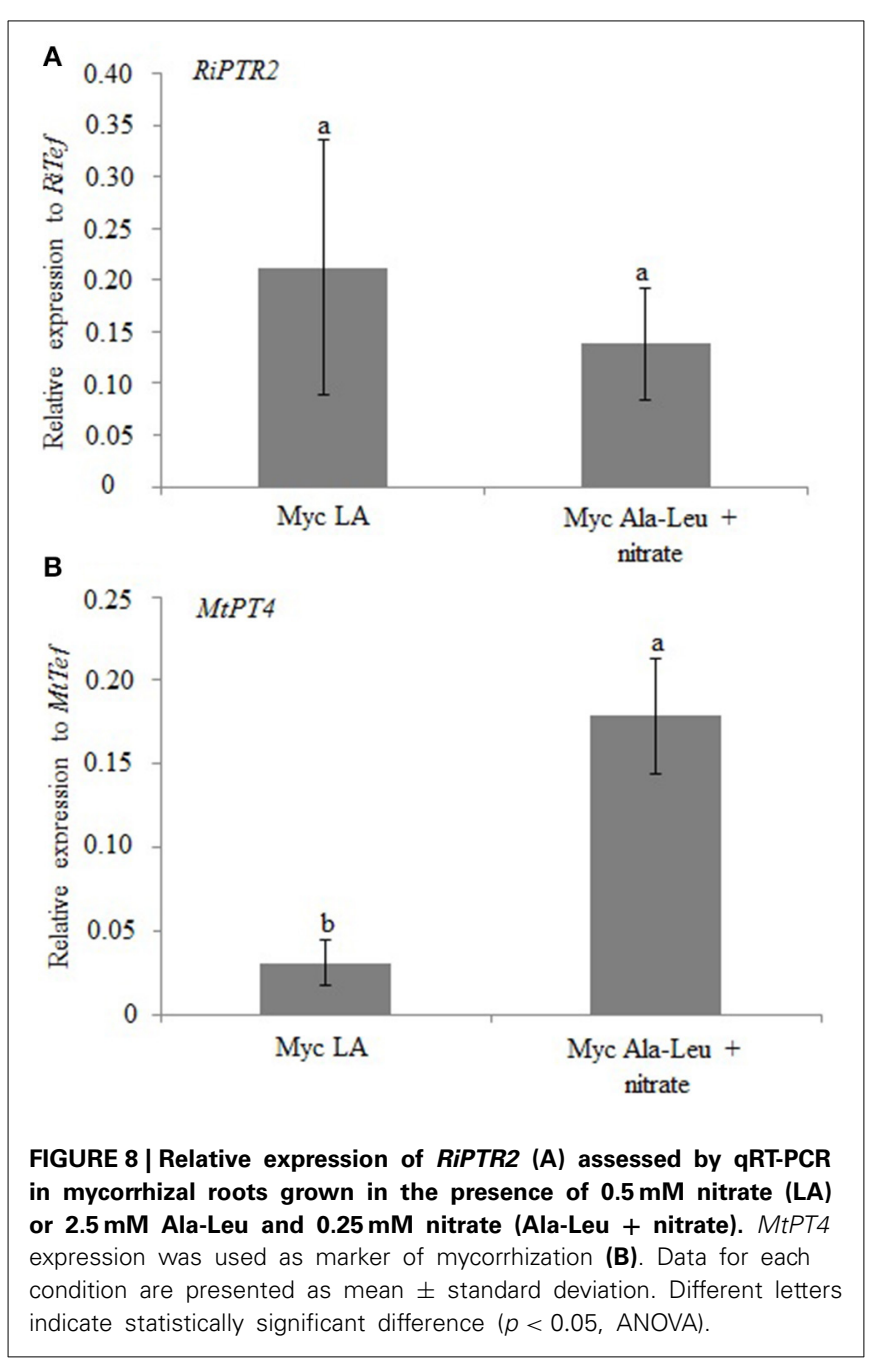

Gene expression data clearly indicated that RiPTR2 is expressed in the ERM, though at a low level, suggesting a potential role in the uptake of dipeptides from the soil solution. However, at least in the analyzed conditions, mRNA abundance was higher in the intraradical phase. The time course experiment clearly showed an up-regulation of RiPTR2 during the colonization process and the establishment of mature mycorrhizas. The analysis of laser-microdissected arbusculecontaining cells confirmed that RiPTR2 is consistently expressed in arbuscules. Since RiPTR2 mRNA abundance does not perfectly match MtPT4 mRNA accumulation (at 28 or 60 dpi) we suggest that RiPTR2 may be expressed not only in arbuscules but also in intercellular hyphae. Evidence that nutrient exchange goes beyond the interface of arbusculated cells and could involve intercellular hyphae as well has been obtained from the expression profile of a fungal monosaccharide transporter (Helber et al., 2011).

A high expression level in the intraradical phase, including arbuscules, where the flux is commonly expected to be directed toward the host plant cells, is puzzling. However, it is worth noticing that additional transporters, a phosphate one (Balestrini et al.,
2007; Tisserant et al., 2012; Fiorilli et al., 2013) and an ammonium one (Pérez-Tienda et al., 2011) from the fungal symbiont were found to be consistently expressed in arbuscules. Dealing with organic N, R. irregularis transcriptomic data also showed the up-regulation of a putative amino acid transporter (contig Glomus_c20826) in the IRM vs. the ERM (Tisserant et al., 2012). These findings suggest that the fungus may reabsorb nutrients released in the periarbuscular space and thus exerts a control over the amount of nutrients delivered to the host. The interface compartment that surrounds the arbuscules is considered acidic (Guttenberger, 2000) and provides a gradient in the electrochemical potential used for the energization of uptake processes. It could be an ideal environment for PTR2 proteins, since they work as proton-coupled transporters and usually show the highest transport activity at acidic pH (Benjdia et al., 2006; Komarova et al., 2008). Interestingly, two M. truncatula PTR genes were also described as mycorrhiza-responsive and their transcripts detected in arbusculated cells (Gomez et al., 2009). We confirmed the upregulation of these two $M$. truncatula genes in mycorrhizal roots compared to control roots in the long term experiment (data not shown).

RiPTR2 gene expression is responsive to the Ala-Leu dipeptide, a possible substrate. We observed a down-regulation of RiPTR2 in the ERM grown in ROC after $24 \mathrm{~h}$ exposure to $10 \mathrm{mM}$ Ala-Leu. A down-regulation was also found for a dipeptide transporter of the ectomycorrhizal fungus $H$. cylindrosporum after exposure to millimolar dipeptide concentrations (Benjdia et al., 2006). By contrast, RiPTR2 expression in whole mycorrhizal roots did not change after $24 \mathrm{~h}$ exposure to $10 \mathrm{mM}$ Ala-Leu. Since these expression values are likely to be mainly representative of the intraradical phase, we can argue that $24 \mathrm{~h}$ are not sufficient to perceive the dipeptide, and that the intraradical RiPTR2 expression is probably also regulated by the plant endogeneous $\mathrm{N}$ status which may not be affected by the short term exposure.

Interestingly, our data from the long term experiment suggest that the AM fungal colonization contributes to the more efficient use of $\mathrm{N}$ when nitrate is present in limiting condition and together with a dipeptide.

A part from yeasts (S. cerevisiae, Schizosaccharomyces pombe) where PTR2 expression is induced by either the presence of amino acids or dipeptides (Kitamura et al., 2012; Ljungdahl and Daignan-Fornier, 2012), very little is known on the regulation of PTR genes in filamentous fungi, with the exception of $H$. cylindrosporum (Benjdia et al., 2006). A sequence showing high similarity to PTR genes was recently found to be expressed during growth on protein-containing substrates in the ectomycorrhizal fungus $P$. involutus (Shah et al., 2013). A PTR2 gene from the biocontrol agent Trichoderma harzianum was up-regulated when the fungus interacted with the plant pathogen Botrytis cinerea (Vizcaíno et al., 2006) and during growth on cell wall of Fusarium solani (Vieira et al., 2013) indicating that PTR genes are involved in the mycoparasitic process. Furthermore, since Glomeromycota are very distantly related to commonly studied fungal species, we may anticipate that regulation of their PTR genes can respond to different environmental clues. 
In their whole our results show that RiPTR2 is expressed in the ERM, the fungus-soil interface, suggesting a role in the uptake of organic $\mathrm{N}$ from soil; however, a stronger expression is consistently observed in the in planta phase, including arbuscules, pointing to a function in the mobilization of organic $\mathrm{N}$ in mycorrhizal roots. Further investigations, not only on the fungal but also on the plant side, will help to obtain a more comprehensive view of the dipeptide metabolism in the AM symbiosis.

\section{AUTHOR CONTRIBUTIONS}

Valentina Fiorilli and Simone Belmondo carried out the majority of the experiments and drafted the manuscript. Nuria Ferrol and Jacob Pérez-Tienda contributed to the experiments on the ERM grown in monoaxenic cultures. Roland Marmeisse participated in the design of the work and helped with the yeast complementation. Luisa Lanfranco coordinated the project and wrote the manuscript. All authors read and approved the final manuscript.

\section{ACKNOWLEDGMENTS}

The Authors express their thanks to Cristina Calcagno for her help in the microdissection experiments and Ascensión Valderas for technical assistance. Research was funded by the University grant (60\%) to Luisa Lanfranco and the Project AGL2012-35611 from the Spanish Ministry of Economy and Competitiveness to Nuria Ferrol. We thank P. Bonfante for access to an unpublished transcripts dataset of Gigaspora margarita (BEG 34). We are grateful to F. Martin and the Mycorrhizal Genomics Initiative consortium for access to unpublished genome data. We also thank S. Torres and collaborators for the use of unpublished genome sequence data from Mucor circinelloides, M. Berbee and collaborators for those of Gonapodya prolifera and Conidiobolus coronatus, and J. Stajich, A. Grygansky, R. Vilgalys and collaborators for those of Umbelopsis ramanniana and Lichtheimia hyalospora. The genome sequence data were produced by the US Department of Energy Joint Genome Institute in collaboration with the user community.

\section{SUPPLEMENTARY MATERIAL}

The Supplementary Material for this article can be found online at: http://www.frontiersin.org/journal/10.3389/fpls.2014. 00436/abstract

\section{REFERENCES}

Balestrini, R., Gomez-Ariza, J., Lanfranco, L., and Bonfante, P. (2007). Laser microdissection reveals that transcripts for five plant and one fungal phosphate transporter genes are contemporaneously present in arbusculated cells. Mol. Plant Microbe Interact. 20, 1055-1062. doi: 10.1094/MPMI-209-1055

Benjdia, M., Rikirsch, E., Müller, T., Morel, M., Corratgé, C., Zimmermann, S. et al. (2006). Peptide uptake in the ectomycorrhizal fungus Hebeloma cylindrosporum: characterization of two di- and tripeptide transporters (HcPTR2A and B). New Phytol. 170, 401-410. doi: 10.1111/j.1469-8137.2006.01672.x

Bonfante, P., and Genre, A. (2010). Mechanisms underlying beneficial plantfungus interactions in mycorrhizal symbiosis. Nat. Commun. 1, 48. doi: 10.1038/ncomms 1046

Cai, H., Hauser, M., Naider, F., and Becker, J. M. (2007). Differential regulation and substrate preferences in two peptide transporters of Saccharomyces cerevisiae. Eukaryot. Cell 6, 1805-1813. doi: 10.1128/EC.00257-06
Cappellazzo, G., Lanfranco, L., Fitz, M., Wipf, D., and Bonfante, P. (2008). Characterization of an amino acid permease from the endomycorrhizal fungus Glomus mosseae. Plant Physiol. 147, 429-437. doi: 10.1104/pp.108.117820

Cliquet, J. B., Murray, P. J., and Boucaud, J. (1997). Effect of the arbuscular mycorrhizal fungus Glomus fasciculatum on the uptake of amino nitrogen by Lolium perenne. New Phytol. 137, 345-349. doi: 10.1046/j.1469-8137.1997.00810.x

Damon, C., Vallon, L., Zimmermann, S., Haider, M. Z., Galeote, V., Dequin, S., et al. (2011). A novel fungal family of oligopeptide transporters identified by functional metatranscriptomics of soil eukaryotes. ISME J. 5, 1871-1880. doi: 10.1038/ismej.2011.67

Dietrich, D., Hammes, U., Thor, K., Suter-Grotemeyer, M., Fluckiger, R., Slusarenko, A. J., et al. (2004). AtPTR1, a plasma membrane peptide transporter expressed during seed germination and in vascular tissue of Arabidopsis. Plant J. 40, 488-499. doi: 10.1111/j.1365-313X.2004.02224.X

Dunkel, N., Hertlein, T., Franz, R., Reuß, O., Sasse, C., Schäfer, T., et al. (2013). Roles of different peptide transporters in nutrient acquisition in Candida albicans. J. Eukaryot. Cell 12, 520-528. doi: 10.1128/EC.00008-13

Edgar, R. C. (2004). MUSCLE: multiple sequence alignment with high accuracy and high throughput. Nucleic Acids Res. 32, 1792-1797. doi: 10.1093/nar/gkh340

Farrell, M., Hill, P. W., Farrar, J. F., Bardgett, R. D., and Jones, D. L. (2011). Seasonal variation in soluble soil carbon and nitrogen across a grassland productivity gradient. Soil Biol. Biochem. 43, 835-844. doi: 10.1016/j.soilbio.2010. 12.022

Fellbaum, C., Gachomo, E. W., Beesetty, Y., Choudhari, S., Strahan, G. D., Pfeffer, P. E., et al. (2012). Carbon availability triggers fungal nitrogen uptake and transport in arbuscular mycorrhizal symbiosis. Proc. Natl. Acad. Sci. U.S.A. 109, 2666-2671. doi: 10.1073/pnas.1118650109

Fiorilli, V., Lanfranco, L., and Bonfante, P. (2013). The expression of GintPT, the phosphate transporter of Rhizophagus irregularis, depends on the symbiotic status and phosphate availability. Planta 237, 1267-1277. doi: 10.1007/s00425013-1842-z

Fitter, A. H., Helgason, T., and Hodge, A. (2011). Nutritional exchanges in the arbuscular mycorrhizal symbiosis: implications for sustainable agriculture. Fungal Biol. Rev. 25, 68-72. doi: 10.1016/j.fbr.2011.01.002

Fortin, J. A., Bécard, G., Declerck, S., Dalpé, Y., St-Arnaud, M., Coughlan, A. P., et al. (2002). Arbuscular mycorrhiza on root-organ cultures. Can. J. Bot. 80, 1-20, doi: 10.1139/b01-139

Giovannetti, M., Sbrana, C., Avio, L., Citernesi, A. S., and Logi, C. (1993). Differential hyphal morphogenesis in arbuscular mycorrhizal fungi during pre-infection stages. New Phytol. 125, 587-593. doi: 10.1111/j.14698137.1993.tb03907.x

Girlanda, M., Perotto, S., and Bonfante, P. (2007). "Mycorrhizal fungi: their habitats and nutritional strategies," in The Mycota IV-Environmental and Microbial Relationships, eds C. P. Kubicek and I. S. Druzhinina (Berlin: Springer), 229-256.

Gomez, S. K., Javot, H., Deewatthanawong, P., Torres-Jerez, I., Tang, Y., Blancaflor, E. B., et al. (2009). Medicago truncatula and Glomus intraradices gene expression in cortical cells harboring arbuscules in the arbuscular mycorrhizal symbiosis. BMC Plant Biol. 9:10. doi: 10.1186/1471-2229-9-10

Gonzàlez-Guerrero, M., Oger, E., Benabdellah, K., Azcón-Aguilar, C., Lanfranco, L., and Ferrol, N. (2010). Characterization of a CuZn superoxide dismutase gene in the arbuscular mycorrhizal fungus Glomus intraradices. Curr. Genet. 56, 265-274. doi: 10.1007/s00294-010-0298-y

Govindarajulu, M., Pfeffer, P. E., Jin, H., Abubaker, J., Douds, D. D., Allen, J. W., et al. (2005). Nitrogen transfer in the arbuscular mycorrhizal symbiosis. Nature 435, 819-823. doi: 10.1038/nature03610

Grigoriev, I. V., Nikitin, R., Haridas, S., Kuo, A., Ohm, R., Otillar, R., et al. (2014). MycoCosm portal: gearing up for 1000 fungal genomes. Nucleic Acids Res. 42, D699-D704. doi: 10.1093/nar/gkt1183

Guidot, A., Verner, M.-C., Debaud, J. C., and Marmeisse, R. (2005). Intraspecific variation in use of different organic nitrogen sources by the ectomycorrhizal fungus Hebeloma cylindrosporum. Mycorrhiza 15, 167-177. doi: 10.1007/s00572-004-0318-1

Guttenberger, M. (2000). Arbuscules of vesicular-arbuscular mycorrhizal fungi inhabit an acidic compartment within plant roots. Planta 211, 299-304. doi: $10.1007 / \mathrm{s} 004250000324$

Hammer, Ø., Harper, D. A. T., and Ryan, P. D. (2001). PAST: paleontological statistics software package for education and data analysis. Palaeont. Elect. 4, 9. Available online at: http://palaeo-electronica.org/2001_1/past/issue1_01.htm 
Harrison, M. J., Dewbre, G. R., and Liu, J. (2002). A phosphate transporter from Medicago truncatula involved in the acquisition of phosphate released by arbuscular mycorrhizal fungi. Plant Cell 14, 2413-2429. doi: 10.1105/tpc. 004861

Hartmann, T., Cairns, T. C., Olbermann, P., Morschhäuser, J., Bignell, E. M., and Krappmann, S. (2011). Oligopeptide transport and regulation of extracellular proteolysis are required for growth of Aspergillus fumigatus on complex substrates but not for virulence. Mol. Microbiol. 82, 917-935. doi: 10.1111/j.13652958.2011.07868.x

Hauser, M., Narita, V., Donhardt, A. M., Naider, F., and Becker, J. M. (2001). Multiplicity and regulation of genes encoding peptide transporters in Saccharomyces cerevisiae. Mol. Membr. Biol. 18, 105-112. doi: $10.1080 / 09687680010029374$

Hawkins, H. J., Johansen, A., and George, E. (2000). Uptake and transport of organic and inorganic nitrogen by arbuscular mycorrhizal fungi. Plant Soil 226, 275-285. doi: 10.1023/A:1026500810385

Helber, N., Wippel, N., Schaarschmidt, S., Hause, B., and Requena, N. (2011). A versatile monosaccharide transporter that operates in the arbuscular mycorrhizal fungus Glomus sp. is crucial for the symbiotic relationship with plants. Plant Cell 23, 3812-3823. doi: 10.1105/tpc.111.089813

Hewitt, E. J. (1966). "Sand and water culture methods used in the study of plant nutrition," in Technical Communication No. 22 (Kent: Commonwealth Agriculture Bureau), 431-432.

Hill, P. W., Farrell, M., and Jones, D. L. (2012). Bigger may be better in soil $\mathrm{N}$ cycling: does rapid acquisition of small L-peptides by soil microbes dominate fluxes of protein-derived $\mathrm{N}$ in soil? Soil Biol. Biochem. 48, 106-112. doi: 10.1016/j.soilbio.2012.01.023

Hodge, A., Campbell, C. D., and Fitter, A. H. (2001). An arbuscular mycorrhizal fungus accelerates decomposition and acquires nitrogen directly from organic material. Nature 413, 297-299. doi: 10.1038/35095041

Homann, O. R., Cai, H., Becker, J. M., and Lindquist, S. L. (2005). Harnessing natural diversity to probe metabolic pathways. PLoS Genet. 1:e80. doi: 10.1371/journal.pgen.0010080

Jones, D. T., Taylor, W. R., and Thornton, J. M. (1992). The rapid generation of mutation data matrices from protein sequences. Comput. Appl. Biosci. 8, 275-282. doi: 10.1093/bioinformatics/8.3.275

Karim, S., Lundh, D., Holmstrom, K. O., Mandal, A., and Pirhonen, M. (2005). Structural and functional characterization of AtPTR3, a stress-induced peptide transporter of Arabidopsis. J. Mol. Model. 11, 226-236. doi: 10.1007/s00894-0050257-6

Kitamura, K., Nakase, M., Tohda, H., and Takegawa, K. (2012). The ubiquitin ligase Ubr11 is essential for oligopeptide utilization in the fission yeast Schizosaccharomyces pombe. Eukaryot. Cell 11, 302. doi: 10.1128/EC.05253-11.

Komarova, N. Y., Thor, K., Gubler, A., Meier, S., Dietrich, D., Weichert, A., et al. (2008). AtPTR1 and AtPTR5 transport dipeptides in planta. Plant Physiol. 148, 856-869. doi: 10.1104/pp.108.123844

Krüger, M., Krüger, C., Walker, C., Stockinger, H., and Schußler, A. (2012). Phylogenetic reference data for systematics and phylotaxonomy of arbuscular mycorrhizal fungi from phylum to species level. New Phytol. 193, 970-984. doi: 10.1111/j.1469-8137.2011.03962.x

Kuzyakov, Y., and Xu, X. (2013). Competition between roots and microorganisms for nitrogen: mechanism and ecological significance. New Phytol. 198, 656-669. doi: 10.1111/nph.12235

Lanfranco, L., Guether, M., and Bonfante, P. (2011). "Arbuscular mycorrhizas and $\mathrm{N}$ acquisition by plants," in Ecological Aspects of Nitrogen Metabolism in Plants, eds J. C. Polacco and C. D. Todd (Hoboken, NJ: John Wiley \& Sons, Inc.), 52-68.

Leigh, J., Hodge, A., and Fitter, A. H. (2009). Arbuscular mycorrhizal fungi can transfer substantial amounts of nitrogen to their host plant from organic material. New Phytol. 181, 199-207. doi: 10.1111/j.1469-8137.2008.02630.x

Lin, K., Limpens, E., Zhang, Z., Ivanov, S., Saunders, D. G. O., Mu, D., et al. (2014). Single nucleus genome sequencing reveals high similarity among nuclei of an endomycorrhizal fungus. PLoS Genet. 10:e1004078. doi: 10.1371/journal.pgen. 1004078

Lipson, D., and Näsholm, T. (2001). The unexpected versatility of plants: organic nitrogen use and availability in terrestrial ecosystems. Oecologia 128, 305-316. doi: $10.1007 / \mathrm{s} 004420100693$

Ljungdahl, P. O., and Daignan-Fornier, B. (2012). Regulation of amino acid, nucleotide, and phosphate metabolism in Saccharomyces cerevisiae. Genetics 190, 885-929. doi: 10.1534/genetics.111.133306
Minet, M., Dufour, M. E., and Lacroute, F. (1992). Complementation of mutants by Arabidopsis thaliana cDNA. Plant J. 32, 417-422. doi: 10.1046/j.1365313X.1992.t01-38-00999.x

Näsholm, T., Kielland, K., and Ganeteg, U. (2009). Uptake of organic nitrogen by plants. New Phytol. 182, 31-48. doi: 10.1111/j.1469-8137.2008.02751.x

Newstead, S. (2014). Molecular insights into proton coupled peptide transport in the PTR family of oligopeptide transporters. Biochem. Biophys. Acta. doi: 10.1016/j.bbagen.2014.05.011. [Epub ahead of print].

Pérez-Tienda, J., Testillano, P. S., Balestrini, R., Fiorilli, V., Azcon-Agiular, C., and Ferrol, N. (2011). GintAMT2, a new member of the ammonium transporter family in the arbuscular mycorrhizal fungus Glomus intraradices. Fungal Genet. Biol. 48, 1044-1055. doi: 10.1016/j.fgb.2011.08.003

Pérez-Tienda, J., Valderas, A., Camañes, G., García-Agustín, P., and Ferrol, N. (2012). Kinetics of $\mathrm{NH}_{4}^{+}$uptake by the arbuscular mycorrhizal fungus Rhizophagus irregularis. Mycorrhiza 22, 485-491. doi: 10.1007/s00572-0120452-0

Perry, J. R., Basrai, M. A., Steiner, H. Y., Naider, F., and Becker, J. M. (1994). Isolation and characterization of a Saccharomyces cerevisiae peptide transport gene. Mol. Cell. Biol. 14, 104-115. doi: 10.1128/MCB.14.1.104

Rasmussen, R. (2001). "Quantification on the LightCycler instrument," in Rapid Cycle Real-Time PCR: Methods and Applications, eds S. Meuer, C. Wittwer, and K. Nakagawara (Heidelberg: Springer-Verlag), 21-34.

Reuß, O., and Morschhäuser, J. (2006). A family of oligopeptide transporters is required for growth of Candida albicans on proteins. Mol. Microbiol. 60, 795-812. doi: 10.1111/j.1365-2958.2006.05136.x

Rose, M. D., Winston, F., and Hieter, P. (1990). Methods in Yeast Genetics: A Laboratory Course Manual. New York, NY: Cold Spring Harbor Laboratory Press.

Schimel, J. P., and Bennet, J. (2004). Nitrogen mineralization: challenges of a changing paradigm. Ecology 85, 591-602. doi: 10.1890/03-8002

Schmidt, S., Torgny Näsholm, T., and Rentsch, D. (2014). Organic nitrogen. New Phytol. 203, 29-31. doi: 10.1111/nph.12851

Shah, F., Rineau, F., Canbäck, B., Johansson, T., and Tunlid, A. (2013). The molecular components of the extracellular protein-degradation pathways of the ectomycorrhizal fungus Paxillus involutus. New Phytol. 200, 875-887. doi: 10.1111/nph.12425

Tamura, K., Peterson, D., Peterson, N., Stecher, G., Nei, M., and Kumar, S. (2011). MEGA5: molecular evolutionary genetics analysis using maximum likelihood, evolutionary distance, and maximum parsimony methods. Mol. Biol. Evol. 28, 2731-2739. doi: 10.1093/molbev/msr121

Tisserant, E., Kohler, A., Dozolme-Seddas, P., Balestrini, R., Benabdellah, K., Colard, A., et al. (2012). The transcriptome of the arbuscular mycorrhizal fungus Glomus intraradices (DAOM 197198) reveals functional tradeoffs in an obligate symbiont. New Phytol. 193, 755-769. doi: 10.1111/j.14698137.2011.03948.x

Tisserant, E., Malbreil, M., Kuo, A., Kohler, A., Symeonidi, A., Balestrini, R., et al. (2013). Genome of an arbuscular mycorrhizal fungus provides insight into the oldest plant symbiosis. Proc. Natl. Acad. Sci. U.S.A. 110, 20117-20122. doi: 10.1073/pnas. 1313452110

Trouvelot, A., Kough, J. L., and Gianinazzi-Pearson, V. (1986). "Mesure du taux de mycorrhization VA d'un système radiculaire. Recherche de méthodes d'estimation ayant une signification fonctionnelle," in Physiological and Genetical Aspects of Mycorrhizae, eds V. Gianinazzi-Pearson and S. Gianinazzi (Paris: INRA), 217-221.

Vieira, P. M., Coelho, A. S. G., Steindorff, A. S., de Siqueira, S. J. L., Silva, R., and Ulhoa, C. J. (2013). Identification of differentially expressed genes from Trichoderma harzianum during growth on cell wall of Fusarium solani as a tool for biotechnological application. BMC Genom. 14:177. doi: 10.1186/1471-216414-177

Vizcaíno, J. A., Cardoza, R. E., Hauser, M., Hermosa, R., Rey, M., Llobell, A., et al. (2006). ThPTR2, a di/tri-peptide transporter gene from Trichoderma harzianum. Fung. Genet. Biol. 43, 234-246. doi: 10.1016/j.fgb.2005. 12.003

Warren, C. R. (2014). Organic N molecules in the soil solution: what is known, what is unknown and the path forwards. Plant Soil 375, 1-19. doi: 10.1007/s11104013-1939-y

Whiteside, M. D., Garcia, M. O., and Treseder, K. K. (2013). Amino acid uptake in arbuscular mycorrhizal plants. PLOS ONE 7:e47643. doi: 10.1371/journal.pone. 0047643 
Wipf, D., Benjdia, M., Tegeder, M., and Frommer, W. B. (2002). Characterization of a general amino acid permease from Hebeloma cylindrosporum. FEBS Lett. 528, 119-124. doi: 10.1016/S0014-5793(02)03271-4

Zocco, D., Van Aarle, I. M., Oger, E., Lanfranco, L., and Declerck, S. (2011). Fenpropimorph and fenhexamid impact phosphorus translocation by arbuscular mycorrhizal fungi. Mycorrhiza 21, 363-374. doi: 10.1007/s00572-010-0344-0

Conflict of Interest Statement: The authors declare that the research was conducted in the absence of any commercial or financial relationships that could be construed as a potential conflict of interest.

Received: 27 June 2014; accepted: 15 August 2014; published online: 03 September 2014.
Citation: Belmondo S, Fiorilli V, Pérez-Tienda J, Ferrol N, Marmeisse R and Lanfranco $L$ (2014) A dipeptide transporter from the arbuscular mycorrhizal fungus Rhizophagus irregularis is upregulated in the intraradical phase. Front. Plant Sci. 5:436. doi: $10.3389 /$ fpls.2014.00436

This article was submitted to Plant Traffic and Transport, a section of the journal Frontiers in Plant Science.

Copyright (C) 2014 Belmondo, Fiorilli, Pérez-Tienda, Ferrol, Marmeisse and Lanfranco. This is an open-access article distributed under the terms of the Creative Commons Attribution License (CC BY). The use, distribution or reproduction in other forums is permitted, provided the original author(s) or licensor are credited and that the original publication in this journal is cited, in accordance with accepted academic practice. No use, distribution or reproduction is permitted which does not comply with these terms. 